ROCZNIK ADMINISTRACJI PUBLICZNEJ 2018 (4)

ARTYKUŁY Polityki publiczne / Public Policies

DOI 10.4467/24497800RAP.18.010.9225

http://www.ejournals.eu/RAP/

ISSN 2449-7800 (online), ISSN 2449-7797 (druk), s. 186-199

MACIES P. GAPSKI ${ }^{1}$

\title{
Prawo do świadczeń z pomocy społecznej w świetle Konstytucji RP
}

\section{Wprowadzenie}

Świadczenie jest fundamentalną instytucją prawa pomocy społecznej, czy nawet szerzej - całego prawa zabezpieczenia społecznego. Realizacja prawa do zabezpieczenia społecznego polega przede wszystkim na świadczeniach wypłacanych lub kierowanych $\mathrm{w}$ innej formie do osób potrzebujących, w podeszłym wieku, znajdujących się bez pracy, chorych, niepełnosprawnych lub z innych przyczyn niezdolnych do zaspokojenia swoich potrzeb. Cechy indywidualne, charakterystyczne dla poszczególnych świadczeń pozwalają na wyróżnienie w ramach zabezpieczenia społecznego świadczeń z zakresu ubezpieczeń społecznych, zabezpieczenia społecznego oraz pomocy społecznej. Analizowane poniżej świadczenia z pomocy społecznej mają charakter nieekwiwalentny, powszechny oraz zróżnicowany. Prawo do świadczenia nie jest uzależnione od podlegania ubezpieczeniu społecznemu i opłacania z tego tytułu składek, zatrudnienia czy też legitymowania się odpowiednim stażem pracowniczym. W związku z powyższym wskazuje się, że obejmują one wszystkich obywateli. Dodatkowo, w przeciwieństwie do świadczeń z tytułu ubezpieczenia lub zaopatrzenia społecznego, nie mają jedynie charakteru pieniężnego, gdyż przyjmują również postać niepieniężną - usługową lub rzeczową ${ }^{2}$.

W obowiązującej Konstytucji RP z 1997 r. ${ }^{3}$ nie znalazły się normy, które wprost statuują prawo do pomocy społecznej czy też konkretnego świadczenia $\mathrm{z}$ tego tytułu. Pomimo zauważonego braku możliwe jest wskazanie

${ }^{1}$ Dr Maciej P. Gapski, adiunkt w Katedrze Administracyjnego Prawa Gospodarczego, Wydział Prawa, Prawa Kanonicznego i Administracji, Katolicki Uniwersytet Lubelski Jana Pawła II, Wiceprezes Samorządowego Kolegium Odwoławczego w Lublinie.

${ }^{2}$ Szerzej na temat problematyki świadczeń społecznych zob. I. Sierpowska, Pomoc społeczna jako administracja świadczaca, Warszawa 2012, s. 197-224.

${ }^{3}$ Konstytucja Rzeczypospolitej Polskiej z dnia 2 kwietnia 1997 r., Dz.U. Nr 78, poz. 483 ze sprost. i zm. 
konstytucyjnych zasad, norm i wartości, które odnoszą się do omawianej problematyki.

Wśród całokształtu wartości i norm określonych w Konstytucji i odnoszących się do sfery praw socjalnych jednostek na szczególną uwagę w kontekście prawa do świadczeń z pomocy społecznej zasługuje godność człowieka, będąca fundamentem wszystkich wolności i praw, a także zasada pomocniczości oraz sprawiedliwości społecznej. Wydaje się, że godność, pomocniczość oraz sprawiedliwość w sposób najgłębszy znajdują odniesienie do problematyki dotyczącej pomocy społecznej. Doprecyzowanie owych zasad ma swój wyraz w szczegółowych normach konstytucyjnych regulujących kwestie zakresu wolności praw ekonomicznych, socjalnych i kulturalnych. W odniesieniu do pomocy społecznej należy zwrócić w szczególności uwagę na art. 67, 68, 69, 71 i 72 Konstytucji.

$\mathrm{W}$ dalszej części przeanalizowane zostaną $\mathrm{w}$ odniesieniu do prawa do świadczenia $\mathrm{w}$ prawie pomocy godność, pomocniczość oraz sprawiedliwość społeczna. Na końcu uwaga zostanie skupiona na regulacjach konstytucyjnych odnoszących się bezpośrednio do praw socjalnych.

\section{Godność człowieka - podstawa praw socjalnych}

Zgodnie $\mathrm{z}$ art. 30 Konstytucji RP przyrodzona i niezbywalna godność człowieka stanowi źródło wolności i praw człowieka i obywatela. Jest ona nienaruszalna, a jej poszanowanie i ochrona jest obowiązkiem władz publicznych.

Odwołanie się w Konstytucji do godności człowieka oraz uznanie jej za wartość o pierwotnym wobec państwa i nadrzędnym wobec prawa stanowionego znaczeniu jest niezmierne istotne $\mathrm{z}$ punktu widzenia wszystkich wartości, zasad i norm w niej zawartych. Przyjmuje się, że powołany przepis rozstrzyga jednoznacznie o uznaniu człowieka za podmiot prawa oraz bezwzględnej i równej ochronie tej podmiotowościł. Godność człowieka, jako pojęcie podstawowe dla cywilizacji i kultury europejskiej, zakłada uznanie go za najwyższą wartość, niezależnie od cech osobniczych oraz własnych zachowań, ogranicza ustawodawcę w decydowaniu o podmiotowym i wolnościowym statusie człowieka, a także wyznacza kierunki wykładni przepisów chroniących podstawowe prawa ${ }^{5}$. Powyższe twierdzenie znajduje swój wyraz również w preambule, gdzie wskazano, że stosowanie Konstytucji powinno odbywać się z dbałością o zachowanie przyrodzonej godności człowieka.

Godność jest istotowo związana z bytem każdego człowieka, dlatego też jest niezbywalna, a z zasady jej nienaruszalności wynika bezwzględny zakaz

${ }^{4}$ L. Bosek [w:] Konstytucja RP. Komentarz, t. 1, L. Bosek, M. Safian (red.), Warszawa 2016, s. 723.

${ }^{5}$ Ibidem. Zob. także P. Tuleja, Stosowanie Konstytucji RP w świetle zasady jej nadrzędności (wybrane problemy), Kraków 2003, s. 124. 
jej naruszania skierowany do wszystkich podmiotów ${ }^{6}$. W związku z bardzo szerokim oddziaływaniem omawianej wartości należy ją łączyć z poszanowaniem wszystkich wartości uznanych i reprezentowanych przez człowieka ${ }^{7}$.

Pomimo powyższego twierdzenia doktryna prawa konstytucyjnego w sposób niejednolity odnosi się do problematyki odziaływania godności na system praw i wolności człowieka ${ }^{8}$. $Z$ jednej strony bowiem przyjmuje się, że godność łączy się z całym systemem praw człowieka, z drugiej natomiast wskazuje na ścisłe powiązanie godności wyłącznie z osobistymi prawami wolnościowymi i równocześnie uznaje jej ograniczony wpływ na treść praw ekonomicznych, socjalnych czy kulturalnych?.

Przywołane powyżej wątpliwości nie stanowią jednak przeszkody do uznania, że prawa o charakterze ekonomicznym i socjalnym są również oparte i wprost odnoszą się do godnościowych korzeni, chociaż liczne szczegółowe elementy tych praw wyznaczone są jedynie poprzez ustawodawstwo zwykłe. Dotyczy to także prawa pomocy społecznej, które nie ma pełnego zakotwiczenia w treści przepisów Konstytucji.

Powyższa teza znajduje odzwierciedlenie w orzecznictwie Trybunału Konstytucyjnego, gdzie wskazano, że „przesłanką poszanowania (...) godności człowieka jest między innymi istnienie pewnego minimum materialnego, zapewniającego jednostce możliwość samodzielnego funkcjonowania w społeczeństwie oraz stworzenie każdemu człowiekowi szans na pełny rozwój osobowy w otaczającym go środowisku kulturowym i cywilizacyjnym" ${ }^{10}$. Dodatkowo zasadne jest podkreślenie, że z samego tekstu Konstytucji wynika, iż szereg uprawnień o charakterze ekonomicznym i socjalnym wyznaczanych jest dopiero na poziomie ustawodawstwa zwykłego ${ }^{11}$.

Należy równocześnie powołać się na trafny wniosek doktrynalny, że oddziaływanie wartości, jaką jest godność, na prawa ekonomiczne i socjalne wiąże się przede wszystkim z obowiązkiem organów publicznych do zapewnienia każdemu odpowiednich warunków życia ${ }^{12}$. Prawidłowa interpretacja powyższego obowiązku powinna łączyć się nie z powinnością zapewnienia obywatelom wysokiego poziomu materialnego egzystencji, ale

${ }^{6}$ Por. P. Tuleja, Stosowanie Konstytucji RP..., s. 124-124 wraz z przytoczonym tam wyrokiem TK z dnia 4 kwietnia 2001 r., K 11/00, OTK ZU 2001, nr 3, poz. 54.

${ }^{7}$ B. Banaszak, M. Jabłoński [w:] Konstytucje Rzeczypospolitej oraz komentarz do Konstytucji RP z 1997 r., J. Boć (red.), Wrocław 1998, s. 67.

8 P. Tuleja, Stosowanie Konstytucji RP..., s. 125-126; L. Bosek [w:] Konstytucja RP. Komentarz..., s. 740. Por. także A Zieliński, Pojmowanie godności ludzkiej w świetle praw ekonomicznych i socjalnych [w:] Godność człowieka a prawa ekonomiczne i socjalne. Księga Jubileuszowa wydana w piętnastą rocznicę ustanowienia Rzecznika Praw Obywatelskich, Warszawa 2003, s. 51.

${ }^{9}$ L. Bosek w: Konstytucja RP, Komentarz..., s. 740-741.

${ }^{10}$ Tak w powołanym powyżej wyroku TK z dnia 4 kwietnia 2001 r., K 11/00, cyt. za P. Tuleją, Stosowanie Konstytucji RP..., s. 125.

${ }^{11}$ Ibidem, s. 126.

${ }^{12}$ Tak A Zieliński, Pojmowanie godności ludzkiej..., s. 53. 
z nakazem tworzenia pozytywnych warunków do samodzielnego zaspokajania przez obywateli swoich potrzeb. Podmioty publiczne mają wkraczać wyłącznie w celu ochrony godności człowieka, gdy zagrożona jest jego egzystencja na określonym, minimalnym poziomie. Należy wątpić natomiast, czy racjonalne, efektywne, a nawet sprawiedliwe jest istnienie takiego modelu państwa, w którym realizacja praw socjalnych polega na ich szerokim finansowaniu ze środków publicznych ${ }^{13}$.

Konkludując, należy podkreślić, że godność człowieka, jako wartość pierwotna, niezbywalna i nienaruszalna, stanowi podstawę nie tylko wolności i praw człowieka o charakterze wolnościowym, ale również ekonomicznym i socjalnym. Oddziaływanie godności na prawo pomocy społecznej wyrażać się powinno w obowiązku podmiotów publicznych wspierania osób, które z przyczyn obiektywnych nie mogą zaspokoić swoich podstawowych potrzeb egzystencjalnych. Zapewnienie poszanowania godności nie pozostaje przy tym $\mathrm{w}$ bezpośrednim związku $\mathrm{z}$ ekonomicznym poziomem życia jednostki. Godność człowieka wyznacza niejako konieczny, podstawowy zakres świadczenia z pomocy społecznej, którym jest zapewnienie każdej osobie ludzkiej minimum egzystencji.

\section{Zasada pomocniczości a prawo do świadczenia z pomocy społecznej}

Wyrażona w preambule do Konstytucji i rozwijana w kolejnych jej normach zasada pomocniczości w sposób istotny oddziałuje na cały system prawa pomocy społecznej. Idea pomocniczości, wywodzona z filozofii greckiej oraz rozwinięta w katolickiej nauce społecznej, jak żadna inna zasada wyznacza władzy publicznej obowiązki oraz granice w zakresie wspierania osób znajdujących się w trudnej sytuacji życiowej ${ }^{14}$.

Chociaż zasada pomocniczości nie ma swojej legalnej definicji, to zawarta w niej treść jest jednolicie odczytywana w doktrynie prawa, a podstawowy wymiar odnosi się do właściwych relacji między jednostką, społecznościami oraz państwem. Powszechnie przytaczana definicja pomocniczości zawarta została w encyklice papieża Piusa XI Quadragesimo anno z 1931 r., gdzie wskazano: „co jednostka $z$ własnej inicjatywy i własnymi siłami może zdziałać, tego jej nie wolno wydzierać na rzecz społeczeństwa; podobnie niesprawiedliwością, szkodą społeczną i zakłóceniem ustroju jest zabieranie mniejszym i niższym społecznościom tych zadań, które mogą spełnić, i przekazywanie ich społecznościom większym i wyższym. Każda akcja społeczna ze swego celu i ze swej natury ma charakter pomocniczy; winna pomagać członkom organizmu społecznego, a nie niszczyć ich lub wchłaniać”.

${ }^{13}$ W. Łączkowski, Ekonomiczne i socjalne prawa człowieka a dobro wspólne [w:] Godność człowieka a prawa ekonomiczne i socjalne..., s. 39-40.

${ }^{14}$ T. Bąkowski, Administracyjnoprawna sytuacja jednostki $w$ świetle zasady pomocniczości, Kraków 2007, s. 31 i n. 
Omawiana zasada stanowi podstawę podziału zadań pomiędzy obywateli, różne struktury społeczne (stowarzyszenia, fundacje), samorząd terytorialny oraz państwo ${ }^{15}$. Istotne $\mathrm{z}$ punktu widzenia pomocniczości jest zapewnienie swobodnej możliwości działania obywatelom, a tylko zadania, których nie są $\mathrm{w}$ stanie wykonać samodzielnie, powinny być przypisane wyższym strukturom społecznym - najpierw samorządowi terytorialnemu, a dopiero następnie państwu ${ }^{16}$. Zasada pomocniczości z jednej strony zakłada odpowiedzialność obywateli za własne sprawy oraz wolność w realizacji własnych zamierzeń i planów, które struktury wyższego rzędu powinny respektować i szanować, $\mathrm{z}$ drugiej natomiast nakłada na podmioty publiczne powinność wspierana jednostek, gdy samodzielnie nie są one w stanie realizować swoich zadań i zaspokajać podstawowych potrzeb bytowych.

Odnosząc zasadę pomocniczości do sfery praw socjalnych, należy podnieść, że podmioty publiczne mają obowiązek wspierać jednostki w zapewnieniu minimalnego poziomu egzystencji odpowiadającego jej godności, ale nie mogą jej wyręczać i zastępować indywidualnej aktywności ${ }^{17}$. W swej istocie działanie podmiotów publicznych ma jedynie charakter posiłkowy (subsydiarny) w stosunku do aktywności jednostki. Państwo i jego struktury nie są zgodnie z powyższym powołane do zaspokajania potrzeb bytowych ludności, a jedynie mają wspierać jednostki lub rodziny, które z przyczyn przez siebie niezawinionych znajdują się w trudnej sytuacji życiowej.

Prawidłowe rozumienie zasady pomocniczości w odniesieniu do pomocy społecznej zakłada, że pomoc ma charakter uzupełniający, akcesoryjny i może być świadczona wyłącznie tym osobom lub rodzinom, które nie potrafią zaspokoić podstawowych potrzeb. Pomoc społeczna w całym systemie zabezpieczenia społecznego jest ostatnim ze środków przezwyciężenia trudnych sytuacji życiowych, udzielana jest przez podmioty publiczne po wyczerpaniu innych uprawnień ${ }^{18}$.

Należy w tym miejscu podkreślić, że o ile z wartości, jaką jest godność osoby, wynika obowiązek pomocy państwa $\mathrm{w}$ zakresie zapewnienia obywatelom możliwość egzystencji na podstawowym poziomie, to zasada pomocniczości zakłada, iż aktywność podmiotów publicznych w zaspokojeniu potrzeb nie może ograniczyć samodzielności i inicjatywy jednostki. Świadczenia z pomocy społecznej powinny być skierowane wyłącznie do osób, które nie są w stanie samodzielnie zadbać o swoje podstawowe potrzeby i interesy. Wszelkie świadczenia socjalne, które są konstruowane bez

${ }^{15}$ W. Łączkowski, Etyczne aspekty finansowania potrzeb socjalnych ze środków publicznych, „Ruch Prawniczy Ekonomiczny i Socjologiczny” 2004, z. 1, s. 8.

${ }^{16}$ Ibidem.

${ }^{17}$ Zob. szerzej K. Stopka, Zasada pomocniczości w prawie pomocy społecznej, Warszawa 2009, s. 61.

${ }^{18}$ Zob. M.P. Gapski, Prawo do pomocy społecznej w orzecznictwie sądów administracyjnych (wybrane zagadnienia) [w:] Problemy z sadowa ochrona praw człowieka, t. 1, R. Sztychmiler, J. Krzywkowska (red.), Olsztyn 2012, s. 591-592. 
poszanowania zasady pomocniczości, nie tylko ją łamią, ale również oddziałują w sposób negatywny na sprawiedliwość społeczną.

\section{Zasada sprawiedliwości społecznej w odniesieniu do świadczeń z pomocy społecznej}

Wyrażona w preambule oraz art. 2 Konstytucji zasada sprawiedliwości społecznej ma bardzo szeroki zakres oddziaływania. Podobnie jak inne zasady o charakterze generalnym, mające silny związek z wieloma dziedzinami nauki i życia społecznego, bardzo trudno precyzyjnie ją zdefiniować. Celem niniejszych rozważań nie jest wskazywanie ogólnego zakresu oddziaływania wartości i zasad konstytucyjnych czy też ich definiowanie. Odnosząc zasadę sprawiedliwości społecznej do sfery praw socjalnych człowieka, a w szczególności świadczeń z pomocy społecznej, należy mieć na względzie sprawiedliwość w jej aspekcie dystrybutywnym.

W rozważaniach prawniczych bardzo często pojawi się odwołanie do arystotelesowskiej koncepcji sprawiedliwości, w której wyróżniono sprawiedliwość wyrównawczą i rozdzielczą (dystrybutywną). Sprawiedliwość wyrównawcza polega na odpowiednim (proporcjonalnym) odpłaceniu dobrem za dobro ewentualnie złem za zło, a sprawiedliwość rozdzielcza na odpowiednio równym traktowaniu podmiotów wskazujących takie same cechy, uznane za istotne w przypadku rozdzielania dóbr lub nakładania obciążeń ${ }^{19}$. W przypadku sprawiedliwości rozdzielczej (dystrybutywnej) wyróżnia się dwie podstawowe metody rozdysponowywania ograniczonych środków: według potrzeb lub według zasług. W prawie bardzo często sprawiedliwość postrzegana jest jako zasada rozdziału bądź odbioru dóbr albo zasada służąca właściwemu zastosowaniu idei równości ${ }^{20}$.

Zdaniem Trybunału Konstytucyjnego sprawiedliwość społeczna ujmowana $\mathrm{w}$ aspekcie dystrybutywnym wiąże się $\mathrm{z}$ innymi pojęciami, takimi jak równość wobec prawa, solidarność społeczna, minimum bezpieczeństwa socjalnego oraz zabezpieczenie podstawowych warunków egzystencji osób pozostających bez pracy nie z własnej woli ${ }^{21}$. Zagwarantowanie standardów wynikających $\mathrm{z}$ owej sprawiedliwości jest w praktyce niezwykle trudne, gdyż łączy się z koniecznością wyważania interesów i oczekiwań potencjalnych adresatów świadczeń socjalnych z interesami tych, którzy je w ostatecznym rozrachunku finansują za pośrednictwem podatków ${ }^{22}$. Ustawodawca musi wziąć również pod uwagę, że wartością konstytucyjnie chronioną jest nie tylko mająca swoje podstawy w godności człowieka

${ }^{19}$ S. Nitecki, Prawo do pomocy społecznej w polskim systemie prawnym, Warszawa 2008, s. 123.

${ }^{20}$ Ibidem.

${ }^{21}$ Tak P. Tuleja [w:] Konstytucja RP..., s. 245.

${ }^{22}$ Ibidem. 
i pomocniczości konieczność wsparcia socjalnego osób najbardziej potrzebujących, ale również względy finansowe państwa $\mathrm{z}$ zasadą równowagi budżetowej na czele ${ }^{23}$.

W tym też kontekście należy uznać, że z zasady sprawiedliwości społecznej interpretowanej w duchu solidarność wynika taki podział dochodu krajowego, w którym osoby płacące podatki finansują socjalne potrzeby osób znajdujących się w trudnej sytuacji życiowej czy materialnej (osoby lepiej sytuowane finansują $\mathrm{w}$ ramach solidarności potrzeby osób znajdujących się w gorszej sytuacji materialnej). Jednakże należy mieć na uwadze (w świetle zasady sprawiedliwości społecznej), że wartość, jaką jest stabilność finansów publicznych, również należy chronić, co wiąże się z koniecznością racjonalnego, czy nawet ograniczonego, wydatkowania środków na cele socjalne. Warto również wskazać, że wydatkowanie przez podmioty publiczne środków na wskazane cele, w tym na pomoc społeczną, w wysokości przewyższającej zagwarantowanie minimum egzystencji i bez zachowania subsydiarnej roli świadczeń może prowadzić do naruszenia zasady sprawiedliwości społecznej. Dodatkowo przy szerokim wydatkowaniu środków publicznych bez odpowiedniego ograniczenia wynikającego z subsydiarności może dojść do paradoksalnej sytuacji, sprzecznej z zasadą sprawiedliwości społecznej, że osoby o niskich i średnich dochodach, będące najszerszą grupą podatników, będą pokrywały świadczenia socjalne dla osób o wyższych dochodach ${ }^{24}$.

Mając powyższe na uwadze, prawidłowe wydaje się twierdzenie, że zgodnie z zasadą sprawiedliwości społecznej państwo może finansować świadczenia z pomocy społecznej ze środków uzyskanych z podatków od osób, które nie znajdują się w trudnej sytuacji. Aby w pełni zachować zasadę sprawiedliwości, należy przy tym poprzez odwołanie się do zasady pomocniczości przekazywać środki tylko do osób obiektywie potrzebujących. Pełna realizacja norm i standardów konstytucyjnych jest domeną ustawodawcy, który wprowadzając regulacje dotyczące świadczeń z pomocy społecznej, powinien prawidłowo odczytywać wynikającą z nich treść.

\section{Konstytucja a prawo do świadczenia w ujęciu formalnym}

Dodatkowo należy podkreślić, że świadczenia z pomocy społecznej przyznawane są najczęściej $\mathrm{w}$ formie aktu administracyjnego - w szczególności decyzji administracyjnej ${ }^{25}$. Z tych też względów szczególnego znaczenia nabierają standardy konstytucyjne odnoszące się do prawidłowego działania administracji. W tym kontekście istotne są normy konstytucyjne wywodzące się z zasady demokratycznego państwa prawnego, w przede wszystkim zasada legalności, zasada równości wobec prawa, zasada pro-

\footnotetext{
${ }^{23}$ Por. W. Łączkowski, Etyczne aspekty finansowania..., s. 9-13.

${ }^{24}$ Ibidem.

${ }^{25}$ Zob. szerzej I. Sierpowska, Pomoc społeczna..., s. 292-312.
} 
porcjonalności, zasada zaskarżalności decyzji administracyjnych (dwuinstancyjnego postępowania), zasada decentralizacji i zasada sądowej kontroli administracji publicznej.

Konstytucja wyznacza więc ramy prawne dla świadczeń z pomocy społecznej nie tylko $\mathrm{z}$ punktu widzenia prawa materialnego (prawo do świadczenia), ale również w jego aspektach formalnych - proceduralnych. W podstawowym zakresie nakłada na organy pomocy społecznej znajdujące się w strukturze administracji publicznej obowiązek działania na podstawie i w granicach prawa oraz przewiduje, że ich działalność podlega kontroli sądów administracyjnych. Szersza analiza powyższych kwestii, dotyczących przede wszystkim postępowania administracyjnego, wykracza poza ramy tego tekstu.

\section{Konstytucyjne prawo do zabezpieczenia społecznego a prawo do świadczenia z pomocy społecznej}

W doktrynie prawa wskazuje się, że pomoc społeczna jest jednym ze składników zabezpieczenia społecznego ${ }^{26}$, które obejmuje całokształt świadczeń przyznawanych obywatelowi będącemu w potrzebie ze środków publicznych ${ }^{27}$. Podkreśla się również, że w systemie zabezpieczenia społecznego wyodrębnia się ubezpieczenia społeczne, zaopatrzenie społeczne i pomoc społeczną ${ }^{28}$.

Konstytucja przewiduje, że prawo do zabezpieczenia społecznego może powstać $\mathrm{w}$ przypadku niezdolności do pracy ze względu na chorobę lub inwalidztwo oraz osiągnięcie wieku emerytalnego (art. 67 ust. 1), a także pozostawania obywatela, który nie ma środków utrzymania, bez pracy nie z własnej woli (art. 67 ust. 2). Prawo do zabezpieczenia społecznego ograniczone zostało wyłącznie do obywateli polskich ${ }^{29}$, a jego zakres i formy przekazano do uszczegółowienia w ramach ustawodawstwa zwykłego. W związku z przyznaniem prawa do zabezpieczenia społecznego tylko obywatelom polskim przyjmuje się, że art. 67 Konstytucji nie ma charakteru „prawa człowieka”, gdyż nie odnosi się do sytuacji prawnej cudzoziemców ${ }^{30}$.

${ }^{26}$ K. Stopka, Zasada pomocniczości..., s. 146.

${ }^{27}$ L. Garlicki, Komentarz do art. 67 Konstytucji [w:] Konstytucja Rzeczypospolitej Polskiej. Komentarz, t. III, L. Garlicki (red.), Warszawa 2003, teza 4.

${ }^{28}$ I. Sierpowska, Prawo pomocy społecznej, Warszawa 2011, s. 35. Podział systemu zabezpieczenia społecznego na ubezpieczenie społeczne, zaopatrzenie społeczne i opiekę społeczną był przez wiele lat stosowany w niemieckiej doktrynie prawa socjalnego, jednakże w okresie późniejszym przyjęto nową systematykę, zob. szerzej M. Zieleniecki, Prawo do zabezpieczenia społecznego, „Gdańskie Studia Prawnicze” 2005, t. XIII, s. 575-576.

${ }^{29}$ P. Winczorek, Komentarz do Konstytucji Rzeczypospolitej Polskiej z dnia 2 kwietnia 1997 r., Warszawa 2008, s. 161-162.

${ }^{30}$ L. Garlicki, Komentarz do art. 67 Konstytucji..., teza 5. 
Konstytucja przyznaje wąski zakres prawa do zabezpieczenia społecznego, wiążąc je wyłącznie z sytuacją niezdolności do pracy z różnych, wskazanych powyżej względów. Redakcja oraz zakres regulacji zawartej w art. 67 ust. 1 i 2 Konstytucji budzi wątpliwości o podstawowym znaczeniu, czy pomoc społeczna w ogóle mieści się w konstytucyjnym pojęciu zabezpieczenia społecznego ${ }^{31}$ ? O ile bowiem zasadne jest twierdzenie, że jest ona elementem składowym zabezpieczenia społecznego w znaczeniu teoretycznym i doktrynalnym, to wątpliwe jest, czy prawo do pomocy społecznej jest częścią prawa do zabezpieczenia społecznego w ujęciu konstytucyjnym ${ }^{32}$.

Podstawową regulacją prawną określającą zasady realizacji prawa do pomocy społecznej jest obecnie ustawa $\mathrm{z}$ dnia 12 marca 2004 r. o pomocy społecznej ${ }^{33}$. Poprzez ten akt prawy ustawodawca zagwarantował prawo obywatela do zapewnienia mu minimalnego poziomu egzystencji przez podmioty publiczne $\mathrm{w}$ odwołaniu do pomocniczości i sprawiedliwości społecznej, i tym samym zrealizował delegację konstytucyjną.

Z treści art. 67 ust. 1 i 2 Konstytucji nie można jednak wyinterpretować prawa do jakiegokolwiek konkretnego świadczenia i to nie tylko w kontekście pomocy społecznej, ale również ubezpieczenia czy zaopatrzenia społecznego. W doktrynie prawa oraz w orzecznictwie Trybunału Konstytucyjnego, sądów administracyjnych i powszechnych słusznie podkreśla się brak konstytucyjnego prawa do konkretnego świadczenia z systemu zabezpieczenia społecznego ${ }^{34}$.

Istotnym zagadnieniem związanym z prawem do pomocy społecznej jest ustalenie charakteru uprawnienia przysługującego osobie do uzyskania pomocy społecznej w postaci świadczenia od organów publicznych. W doktrynie prezentowane są dwa odrębne poglądy dotyczące tej problematyki.

Z jednej strony przyjmuje się, że prawo do pomocy społecznej jest publicznym prawem podmiotowym osób lub rodzin, które po stronie organów administracji publicznej rodzi obowiązek zaspokojenia uzasadnionego żądania ${ }^{35}$. Innymi słowy, wnioskodawca ma roszczenie o przyznanie określonego świadczenia, jeżeli spełnia ustawowe przesłanki. Odmiennie przyjmuje się, że strona występująca o świadczenie z pomocy społecznej nie

${ }^{31}$ Zob. K. Kolasiński, Konstytucyjne prawo do zabezpieczenia społecznego a nowy system ubezpieczeń społecznych, „Państwo i Prawo” 1999, z. 5, s. 10; M. Zieleniecki, Prawo do zabezpieczenia..., s. 581, a także I. Sierpowska, Pomoc społeczna..., s. 355.

${ }^{32}$ Tak słusznie I. Sierpowska, Pomoc społeczna jako..., s. 356.

${ }^{33}$ Dz.U. z 2018 r. poz. 1508 ze zm.

${ }^{34}$ I. Sierpowska, Pomoc społeczna..., s. 356; K. Stopka, Zasada pomocniczości..., s. 146. Por. częściowo odmiennie W. Jakimowicz, Publiczne prawa podmiotowe, Kraków 2002, s. 257-258. Zob. też wyrok SN z dnia 24 czerwca 2015 r., I UK 371/14, LEX nr 1771087; wyrok SN z dnia 20 października 2016 r., I UK 197/16, LEX nr 2151408; wyrok NSA z dnia 10 lutego 2011 r., I OSK 1771/10, LEX nr 1070795.

${ }^{35}$ Zob. A. Miruć, Zasada pomocniczości w prawie pomocy społecznej, „Administracja. Teoria. Dydaktyka. Praktyka" 2008, nr 3, s. 33. 
ma roszczenia o jego przyznanie, a jedynie o formalne rozpatrzenie wniosku przez właściwy organ pomocy społecznej ${ }^{36}$. Zauważa się przy tym, że w odniesieniu do świadczeń fakultatywnych (uznaniowych) uprawnienie to przyjmuje jedynie postać roszczenia o rozpatrzenie sprawy, natomiast w przypadku świadczeń rozstrzyganych decyzjami związanymi prawo to zbliża się w swym charakterze do publicznego prawa podmiotowego. Nawet w tym ostatnim przypadku, dotyczącym świadczeń tzw. obligatoryjnych (zasiłek stały), nie można jednak w pełni przyznać temu prawu charakteru publicznego prawa podmiotowego ${ }^{37}$.

Warto jednocześnie podkreślić, że rozważania na temat charakteru prawa do pomocy społecznej czy też do skonkretyzowanego świadczenia zaprezentowane powyżej bazują na analizie ustawodawstwa zwykłego, przede wszystkim ustawy o pomocy społecznej. Natomiast w odniesieniu do podjętej problematyki konstytucyjnej istotna jest odpowiedź na pytanie, czy Konstytucja daje podstawy do uznania prawa do pomocy społecznej za publiczne prawo podmiotowe?

Wydaje się, że pomimo wątpliwości co do zakresu regulacji zawartej w art. 67 Konstytucja RP statuuje publiczne prawo podmiotowe do pomocy społecznej, jednakże w bardzo wąskim zakresie. Istotne jest, że świadczenie z pomocy społecznej może być przyznane jedynie w sytuacji, gdy osoba i rodzina w żaden inny sposób nie może zaspokoić swych podstawowych potrzeb. Zgodnie z powołanym powyżej art. 67 Konstytucji świadczenie może być przyznane na wypadek: niezdolności do pracy ze względu na chorobę, inwalidztwo, osiągnięcie wieku emerytalnego, pozostawanie bez pracy nie z własnej woli i nieposiadanie innych środków utrzymania. Konstytucja wyznacza minimalny zakres publicznego prawa podmiotowego do pomocy społecznej i ogranicza go wyłącznie do sytuacji wskazanych w niej wprost, a ich katalog wydaje się zamknięty ${ }^{38}$. Uszczegółowienie zasad i przesłanek udzielania świadczeń z pomocy społecznej delegowano na ustawodawcę, który dysponuje znaczną swobodą w zakresie regulacji prawa do pomocy społecznej i konkretnych świadczeń ${ }^{39}$. Przy braku regulacji ustawowej przyznającej w sposób skonkretyzowany prawo do świadczenia z pomocy społecznej obywatelowi może natomiast przysługiwać oparte na Konstytucji roszczenie związane z zaniechaniem legislacyjnym.

Należy dodatkowo wskazać, że problematyką świadczeń z pomocy społecznej zajmował się Trybunał Konstytucyjny. W wyroku z dnia 20 listopa-

${ }^{36}$ K. Stopka, Zasada subsydiarności a prawo do świadczeń z pomocy społecznej, „Samorząd Terytorialny" 2008, nr 11, s. 43.

${ }^{37}$ Szerzej ibidem, s. 54. Por. także S. Nitecki, Prawo do pomocy społecznej..., s. 182184.

${ }^{38}$ A. Miruć, Konstytucyjne podstawy prawa do pomocy społecznej w Polsce, „Administracja. Teoria. Dydaktyka. Praktyka" 2010, nr 1, s. 86.

${ }^{39}$ S. Nitecki, Prawo do pomocy społecznej..., s. 57. 
da $2001 \mathrm{r}^{40}$, dotyczącym ustalenia zgodności art. 31 ust. 1 (zasiłek okresowy) ustawy z dnia 29 listopada 1990 r. o pomocy społecznej ${ }^{41} \mathrm{z}$ art. 67 ust. 2 Konstytucji RP, wyjaśnił, że niewłaściwa byłaby taka interpretacja powołanego przepisu Konstytucji, z której wynikałoby indywidualne roszczenie o świadczenie przewidziane w każdej z form składających się na zabezpieczenie społeczne. $Z$ orzeczenia Trybunału wynika, zważywszy na subsydiarny charakter pomocy społecznej, że nie można przypisać organom administracji publicznej obowiązku przyznania świadczenia określonym osobom w żądanej przez nie wysokości. Swoje stanowisko Trybunał uzasadniał przede wszystkim względami budżetowymi, w tym w szczególności możliwością destabilizacji budżetu państwa.

Mając na uwadze powyższe rozważania, trzeba przyjąć, że na podstawie Konstytucji osoby i rodziny nie mogą domagać się przyznania im świadczenia z pomocy społecznej w określonej wysokości i formie. Uprawnienie osoby potrzebującej do świadczenia ma tylko wyjątkowo charakter publicznego prawa podmiotowego, którego zakres wynika przede wszystkim z ustawy, a nie wprost z norm konstytucyjnych. Szczegółowa analiza prawa do konkretnego świadczenia powinna być dokonywana nie w kontekście regulacji zawartej w Konstytucji, a ustawodawstwa zwykłego, przede wszystkim zaś ustawy o pomocy społecznej ${ }^{42}$. Konstytucja deleguje bowiem na ustawodawcę obowiązek doprecyzowania przesłanek i zasad przyznawania świadczeń, a samodzielnie w ograniczonym zakresie wpływa na ich zakres. Normy konstytucyjne wyznaczają minimalny poziom świadczeń oraz wskazują (w szczególności w art. 67-72) podmioty i przesłanki, które powinny zostać uwzględnione $\mathrm{w}$ ramach regulacji ustawowych, nie przesądzając o konkretnych rozwiązaniach. W związku z wąskim, a nawet wątpliwym zakresem regulacji konstytucyjnej odnoszącej się do zabezpieczenia społecznego zasadne wydają się postulaty doktrynalne wskazujące na konieczność dokonania stosownych zmian ${ }^{43}$.

\section{Zakończenie}

Wartości i normy konstytucyjne są źródłem gwarancji, a nie praw. Szczególnie w odniesieniu do świadczeń socjalnych spełniają rolę wzorca, który znajduje swoje uszczegółowienie dopiero $\mathrm{w}$ ustawodawstwie zwykłym ${ }^{44}$. Najważniejsze z punktu widzenia prawa do świadczeń z pomocy społecznej są wartości wynikające z godności człowieka, a także zasada pomocniczości oraz sprawiedliwości społecznej, odczytywana w kontekście idei solidarno-

\footnotetext{
${ }^{40}$ Wyrok TK z 20 listopada 2001 r., SK 15/01, Dz.U. Nr 138, poz. 1564.

${ }^{41}$ Dz.U. z 1998 r. Nr 64, poz. 414 ze zm.

${ }^{42}$ S. Nitecki, Prawo do pomocy społecznej..., s. 181-189.

${ }^{43}$ M. Zieleniecki, Prawo do zabezpieczenia..., s. 582.

${ }^{44}$ Por. wyrok NSA z dnia 29 listopada 2016 r., I OSK 836/15, LEX nr 2169834.
} 
ści i równości. W aspekcie wskazanych zasad i wartości można stwierdzić, że Konstytucja gwarantuje każdemu obywatelowi prawo do świadczenia na poziomie zapewnienia minimum egzystencji, przy czym pomoc może być skierowana wyłącznie do osób, które z przyczyn obiektywnych nie potrafią samodzielnie zabezpieczyć swoich potrzeb. Transfer środków publicznych pochodzących z podatków powinien uwzględniać ponadto zasady odnoszące się do stabilności sektora finansów publicznych.

Przepisy konstytucyjne statuujące prawo do zabezpieczenia społecznego wyłącznie w ograniczonym zakresie mogą być uznane za źródło publicznego prawa podmiotowego do świadczeń z pomocy społecznej. Z Konstytucji RP nie można jednak wywieść prawa do jakiegokolwiek skonkretyzowanego świadczenia z pomocy społecznej.

\section{Bibliografia}

Banaszak B., Jabłoński M. [w:] Konstytucje Rzeczypospolitej oraz komentarz do Konstytucji RP z 1997 r., J. Boć (red.), Wrocław 1998.

Bąkowski T., Administracyjnoprawna sytuacja jednostki $w$ świetle zasady pomocniczości, Kraków 2007.

Bosek L. [w:] Konstytucja RP. Komentarz, t. 1, L. Bosek, M. Safian (red.), Warszawa 2016.

Gapski M.P., Prawo do pomocy społecznej w orzecznictwie sądów administracyjnych (wybrane zagadnienia) [w:] Problemy $z$ sądowa ochrona praw człowieka, t. 1, R. Sztychmiler, J. Krzywkowska (red.), Olsztyn 2012.

Garlicki L. [w:] Konstytucja Rzeczypospolitej Polskiej. Komentarz, t. III, L. Garlicki (red.), Warszawa 2003.

Jakimowicz W., Publiczne prawa podmiotowe, Kraków 2002.

Kolasiński K., Konstytucyjne prawo do zabezpieczenia społecznego a nowy system ubezpieczeń społecznych, „Państwo i Prawo” 1999, z. 5.

Łączkowski W., Ekonomiczne i socjalne prawa człowieka a dobro wspólne [w:] Godność człowieka a prawa ekonomiczne i socjalne. Księga Jubileuszowa wydana w piętnasta rocznice ustanowienia Rzecznika Praw Obywatelskich, Warszawa 2003.

Łączkowski W., Etyczne aspekty finansowania potrzeb socjalnych ze środków publicznych, „Ruch Prawniczy Ekonomiczny i Socjologiczny” 2004, z. 1.

Miruć A., Konstytucyjne podstawy prawa do pomocy społecznej w Polsce, „Administracja. Teoria. Dydaktyka. Praktyka" 2010, nr 1.

Miruć A., Zasada pomocniczości w prawie pomocy społecznej, „Administracja. Teoria. Dydaktyka. Praktyka" 2008, nr 3.

Nitecki S., Prawo do pomocy społecznej w polskim systemie prawnym, Warszawa 2008 .

Sierpowska I., Prawo pomocy społecznej, Warszawa 2011.

Sierpowska I., Pomoc społeczna jako administracja świadczaca, Warszawa 2012.

Stopka K., Zasada pomocniczości w prawie pomocy społecznej, Warszawa 2009. 
Stopka K., Zasada subsydiarności a prawo do świadczeń z pomocy społecznej, „Samorząd Terytorialny" 2008, nr 11.

Tuleja P., Stosowanie Konstytucji RP w świetle zasady jej nadrzędności (wybrane problemy), Kraków 2003.

Tuleja P. [w:] Konstytucja RP. Komentarz, t. 1, L. Bosek, M. Safian (red.), Warszawa 2016.

Winczorek P., Komentarz do Konstytucji Rzeczypospolitej Polskiej z dnia 2 kwietnia 1997 r., Warszawa 2008.

Zieleniecki M., Prawo do zabezpieczenia społecznego, „Gdańskie Studia Prawnicze” 2005 , t. XIII.

Zieliński A., Pojmowanie godności ludzkiej w świetle praw ekonomicznych i socjalnych [w:] Godność człowieka a prawa ekonomiczne i socjalne. Księga Jubileuszowa wydana w piętnasta rocznicę ustanowienia Rzecznika Praw Obywatelskich, Warszawa 2003.

\section{Akty prawne}

Konstytucja Rzeczypospolitej Polskiej z dnia 2 kwietnia 1997 r., Dz.U. Nr 78, poz. 483 ze sprost. i zm.

Ustawa z dnia 29 listopada 1990 r. o pomocy społecznej, Dz.U. z 1998 r. Nr 64, poz. 414 ze zm.

Ustawa z dnia 12 marca 2004 r. o pomocy społecznej, Dz.U. z 2018 r. poz. 1508 ze $\mathrm{zm}$.

\section{Orzecznictwo}

Wyrok TK z dnia 4 kwietnia 2001 r., K 11/00, OTK ZU 2001, nr 3, poz. 54.

Wyrok TK z 20 listopada 2001 r., SK 15/01, Dz.U. Nr 138, poz. 1564.

Wyrok SN z dnia 24 czerwca 2015 r., I UK 371/14, LEX nr 1771087.

Wyrok SN z dnia 20 października 2016 r., I UK 197/16, LEX nr 2151408.

Wyrok NSA z dnia 10 lutego 2011 r., I OSK 1771/10, LEX nr 1070795.

Wyrok NSA z dnia 29 listopada 2016 r., I OSK 836/15, LEX nr 2169834.

Streszczenie

Świadczenie jest fundamentalną instytucją prawa pomocy społecznej, czy nawet szerzej - całego prawa zabezpieczenia społecznego. Konstytucja RP z 1997 r. nie przyznała obywatelom wprost prawa do pomocy społecznej lub też konkretnego świadczenia. Pomimo tego braku można wskazać konstytucyjne zasady, normy i wartości, które odnoszą się do omawianej problematyki. Wśród całokształtu wartości i norm określonych w Konstytucji i odnoszących się do sfery praw socjalnych jednostek na szczególną uwagę w kontekście prawa do świadczeń z pomocy społecznej zasługuje godność człowieka, będąca fundamentem wszystkich wolności i praw, a także zasada pomocniczości oraz sprawiedliwości społecznej. Można stwierdzić, że Konstytucja gwarantuje każdemu obywatelowi prawo do świadczeń na poziomie zapewnienia minimum egzystencji, przy czym pomoc może być skierowana wyłącznie do osób, które z przyczyn obiektywnych nie potrafią samodzielnie zabezpieczyć swoich potrzeb. Transfer środków publicznych pochodzących z podatków powinien uwzględniać ponadto zasady odnoszące się do stabilności sektora finansów publicznych.

Słowa kluczowe: pomoc społeczna, świadczenie z pomocy społecznej, godność, zasada pomocniczości, zasada sprawiedliwości społecznej 
The Right to Receive Walfare Benefits in the Light of the Polish Constitution

Abstract

The welfare benefit is a fundamental institution of social assistance law or even entire social security law. The Constitution of Republic of Poland does not grant the citizens a direct right to social assistance or a specific benefit. Nevertheless, it is possible to indicate the constitutional principles, norms and values that relate to the subject in question. Among all the values and norms set forth in the Constitution relating to the social sphere of individuals, special attention should be drawn to the dignity of the human being, which is the foundation of all freedoms and rights, as well as the principle of subsidiarity and social justice. As far as the principles and values are concerned, the constitution guarantees every citizen the right to a welfare benefit which ensures subsistence but provided only for persons who, for objective reasons, cannot afford to protect themselves on their own. The transfer of public funds from taxes should also take into account the rules relating to the sustainability of the public finance sector.

Keywords: social assistance, social benefit, dignity, the principle of subsidiarity, the principle of social justice 